\title{
Serialização da cultura e promoção de imaginários ambivalentes: construindo o "comum-excepcional" em A feiticeira
}

\section{Serialization of culture and promotion of ambivalent imaginaries: building the "common-exceptional" in Bewitched TV series}

Rose de Melo Rocha ${ }^{1}$, Paulo Roberto Ferreira da Cunha ${ }^{2}$

1 Professora do Programa de Pós-Graduação em Comunicação da Escola Superior de Propaganda e Marketing (ESPM). E-mail: rlmrocha@uol.com.br.

2 Coordenador e professor do curso de Comunicação Social da Escola Superior de Propaganda e Marketing (ESPM). E-mail: pcunha@espm.br. 


\section{Resumo}

Este artigo problematiza algumas significações imagéticas e imaginárias articuladas no consumo de narrativas serializadas. Para empreender esta análise, partimos de uma contextualização teórica sobre serialização da cultura e descentralização da cultura de massas, analisando a imagética do consumo articulada na serialização. Voltamo-nos, a seguir, em uma perspectiva histórica, a imagens modelares de estilo de vida, através da disseminação da comunicação de forma massiva em um seriado estadunidense produzido para a TV na década de 1960, A feiticeira. Em paralelo à ação normativa da difusão do referido modelo, contradições e fatores contextuais tensionavam o padrão, evidenciando ações intencionais e involuntárias que dialogavam com parcelas distintas da população não coniventes ou contempladas pelo status quo. Assim, entendemos que há a disseminação de imaginários ambivalentes pela série e no processo de seu consumo.

\section{Palavras-chave}

Serialização da cultura, imagem e imaginário, ambivalência, $A$ feiticeira.

\section{Abstract}

This article problematizes some imagetic meanings articulated to the consumption of serialized narratives. In order to undertake this analysis, we start from a theoretical contextualization about serialization of culture and decentralization of mass culture, analyzing the imagery of consumption articulated in serialization. We turn, then, in a historical perspective, to model lifestyle images, by massively disseminating mass communication in an American television series produced in the 1960s, Bewitched. In parallel with the normative action of the diffusion of this model, contradictions and contextual factors intended the pattern, evidencing involuntary intentional actions that dialogued with distinct portions of the population that were not conniving or contemplated by the status quo. Thus, it is possible to understand that there is the dissemination of ambivalent imaginaries by the series and in the process of their consumption.

\section{Keywords}

Serialization of culture, image and imaginary, ambivalence, Bewitched. 


\section{Serialização da cultura e descentralização da cultura de massas}

Fredric Jameson (1996), crítico da pós-modernidade, tornou-se conhecido por problematizar o modo específico de união entre temporalidade e imagens que, em sua interpretação, caracteriza o capitalismo contemporâneo, interrogandose sobre "a lógica cultural articulada pelas determinações concretas do que se convencionou chamar eufemisticamente de nova ordem mundial" (JAMESON, 1996, p. 5). Analisando diferentes textos culturais (da fotografia, da literatura, da arquitetura, do cinema e provenientes dos meios massivos), Jameson dedica atenção importante ao que nomeia a lexicologia da mídia. Em uma das bases de sua argumentação, o "capitalismo da mídia" corrobora a perda de historicidade típica da dinâmica arrebatadora que Jameson percebe como epicentro do momento pós-moderno do olhar. Nele, criar-se-iam efetivamente novas sensibilidades e novos estados mentais articulados à naturalização, à serialização e à presentificação dos textos visuais, alicerçando um solo comportamental típico do que Guy Debord, ao final da década de 60, nomearia a sociedade do espetáculo, com "tudo o que era vivido diretamente [tornando-se] uma representação" (DEBORD, 1997, p. 13).

Radicalizando a visada debordiana, a questão para Jameson é compreender que tipo de articulação se opera entre o psiquismo das "pessoas pós-modernas" e estas imagens sem historicidade, com "uma nova falta de profundidade" bastante ativa e atraente (JAMESON, 1996, p. 32), repletas de pastiches de formas culturais, emulações de estados de espírito, fragmentos de um passado estilizado e de um mundo que, efetivamente, deveria ser vivido na indistinção entre base e superestrutura. O consumo, nestes termos, é "o consumo do próprio processo de consumo, muito além do de seu conteúdo e dos produtos comerciais mais imediatos" (JAMESON, 1996, p. 282). E é neste aspecto que ele identifica a nuclearidade da serialização como uma ordenadora hegemônica do modo de consumir narrativas midiáticas nos contextos pós-industriais e intensamente tecnologizados: 
não são os produtos comerciais do mercado que se tornam imagens na propaganda, mas sim os próprios processos de diversão e de narrativa da televisão comercial que são, por sua vez, reificados e transformados em mercadorias: a narrativa serializada, com seus segmentos rígidos e quebras temporais reduzidos a fórmulas, a ação das tomadas da câmara sobre o espaço, a história, as personagens e as modas, incluindo também aí o novo processo de produção de celebridades e de estrelas que parece diferente da experiência mais familiar que tínhamos destas questões (JAMESON, 1996, p. 283).

Levando tal argumento adiante, o autor sugere que a serialização, aliada ao que hoje podemos chamar a indústria das celebridades e ao embaralhamento ou desvanecimento das fronteiras entre real e ficcional, está relacionada a uma profunda transformação da esfera pública, marcada pelo "aparecimento de um novo domínio da realidade das imagens, que é a um só tempo ficcional (narrativo) e factual (até as personagens dos seriados são percebidas como estrelas reais)" (JAMESON, 1996, p. 283). É interessante notar como desta realidade inextricavelmente cultural emergem de fato figuras públicas, e neste caso a união entre política e espetáculo, ainda que não toque diretamente a Jameson nesta obra, ganha excepcional gramatura. Hipóteses assim, de um ponto de vista latino-americano, são contemporaneamente contempladas por Omar Rincón, em vários de seus escritos, tanto em sua consideração do potencial narrativo da mídia e do entretenimento quanto ao dirigir duras críticas à cooptação instrumental, estilizada e desideologizante do popular por governos populistas e indústrias culturais inescrupulosas.

É nossa intenção neste artigo analisar uma série específica, $A$ feiticeira ${ }^{3}$, cuja criação remete aos intensos e problemáticos anos 60 , período que Edgar Morin (1999) vai associar ao início do fim da cultura de massas centralizada e monocórdica, e que precisa incluir na sua ideologia narrativa os rebeldes e errantes. Dirigimo-nos, pois, a um espaço-tempo específico, a saber, a pujante e contraditória sociedade norte-americana sessentista, mergulhada na louvação a um 
estilo de vida modelar, exemplar, admirável e pretensamente universal, mas que, cada vez mais, deparava-se com a complexidade e os conflitos sociais, as crises econômicas e as contracorrentes culturais. Contudo, tendo este marco periodizante como escolha metódica, entendemos que as experiências de serialização ali localizadas - e o modo como dialogam com sujeitos e coletividades - podem ser entendidas como um dos pilares de uma mutação ainda em processo na relação entre audiências e produtos culturais massivos, em específico os serializados.

Assim, interessa de modo bastante específico auscultar como nesta série de sucesso opera-se a promoção do que aqui nomeamos imaginários ambivalentes. Esta ambivalência, segundo a percebemos, é intrínseca à produção imagética da série. A fragmentação em blocos narrativos convive com a continuidade subsumida na essência da ideia de um consumo pulsado e contínuo de uma narrativa serial, no que as músicas-tema desempenham papel fundamental; no plano da representação, o ficcional dirige-se ao cotidiano, ao dia a dia, tanto ao doméstico como indiretamente ao mundo do trabalho; e, assim, o ordinário convive com a excepcionalidade. Mas, igualmente, alcança o borramento tensivo apontado por Jameson, e em ao menos dois aspectos. Em primeiro lugar, nota-se a mescla entre realidades vividas pelos atores e o desenvolvimento da trama: foi o caso da gravidez ficcional da protagonista Samantha, interpretada pela atriz Elizabeth Montgomery, que efetivamente havia engravidado.

Montgomery, filha de um ator hollywoodiano e de uma estrela da Broadway, materializa a transição - ou, digamos, a expansão - da indústria do entretenimento para as telinhas domésticas, não mais se restringindo exclusivamente às produções cinematográficas e espetáculos teatrais. E, nesta migração, o alimento serial beneficia-se do que fica em aberto, em uma narrativa que se conclui sem nunca chegar ao fim, mas que muito depende de pitadas pessoais, como toda a curiosidade despertada em torno da atriz principal e sua vida privada para cimentar a relação imagem midiática/imaginário espectorial. Este, aliás, é outro borramento: a vida dos atores torna-se pública-privada, tornando a fantasmática ideia de intimidade um recurso a mais no encanto das imagens. É o que Michel Kokoreff, nos anos 
90, vai identificar na inversão banalizante típica dos processos de celebrização pós-pós-modernos, estes nos quais o novo star system inclui e celebra o cidadão comum explorando as características ordinárias e/ou vulgares de celebridades incomuns - tópicos não por acaso cada vez mais característicos dos realities shows.

Em uma segunda direção, a série institui uma temporalização própria ao cotidiano do espectador doméstico. $\mathrm{O}$ consumo regular de uma narrativa midiática em pedaços e ofertada a domicílio envolve uma educação dos sentidos. O que se prepara aí? Se a experiência das locomotivas é associada à constituição do receptor (de imagens em movimento, que se fusionam em presença, o cinema na linha de frente), a série televisa anuncia um receptor que é indiretamente incluído na trama, em longo prazo, e sequencialmente. Debord (1997) já antevira tal perspectiva, explicitando a introjeção do espetáculo nos planos ordinários, não só com as mercadorias legislando e participando da produção "adequada" da vida privada, mas implicando posteriormente no consumo social das imagens (deste próprio cotidiano, podemos acrescentar).

Tecendo a indistinção real/ficcional, o homem comum, o sujeito médio bem-sucedido retratado na série (como na figura do marido de Samantha, de seu patrão e vizinhos), convive com um comum-extraordinário: a dona de casa exemplar é, também, uma feiticeira. Mas, e isto não é de se estranhar, até a magia tem limites. A dona de casa/feiticeira vez ou outra se contém, isto quando considera, digamos assim, que passou dos limites. Tal situação poderá envolver a promoção de um estilo de vida superlativo, luxuoso demais, excêntrico demais para os padrões humanos e os referentes classistas dos quais é evidentemente tributária e cuidadora zelosa. Ou, ainda, quando sua mágica resulta em uma confusão entre mundo cotidiano e mundo fantástico - onde não existem limites e a curva do tempo se dobra e desdobra como plástico.

\section{Imagens, imaginários, imagéticas do consumo}

Refletindo sobre a imagética do consumo mediada (na referência a objetos, posses e estilos de vida desejáveis) e midiatizada (no consumo da própria série 
como referente de um modo de ser e olhar para o mundo, suas temporalidades e seus conflitos) por $A$ feiticeira, percebemos como o caráter serial - combinado a um plot que mescla retratos banais do cotidiano a experiências mágicas, sobre-humanas - compõe um magma imaginário curioso. Há certa indistinção entre imagerie e imaginário, de modo que, bem se pode sugerir, a feitiçaria de Samantha, usada para equacionar problemas do cotidiano de sua família terrena ou dilemas existenciais e extemporâneos de sua família de bruxos, aproximase do trabalho de seu marido em uma agência de publicidade, que se esmera, nem sempre com sucesso, em tornar as narrativas de sonho publicitárias algo perfeitamente adequado às materialidades e serviços vendidos e às fantasias que, via de regra, deveriam muito concretamente ser realizadas.

A serialização das imagens-estilo-de-vida atua, de fato, em uma dinâmica ambivalente: de um lado, introjeta certo suspense à monotonia da every-day-life o que virá a seguir, seja no enredo, seja em relação à continuidade ou interrupção da própria série, iniciando de maneira sutil e extremamente eficaz a fidelização e solidariedade do espectador em relação ao produto e a responsabilização por seu fim ou por sua perenidade -, de outro, ao repetir-se serialmente, equaciona de forma magistral o paradoxo moderno. A experiência temporal torna-se "uma acumulação infinita de intervalos equivalentes". A fragmentação torna-se unidade, "o fim não é nada, o desenrolar é tudo" (DEBORD, 1997, p. 17, 103), chegando, contemporaneamente, à performatização do cotidiano e das personalidades. Como diz Rincón (2006, p. 19-24), as narrativas e culturas midiáticas configuram estratégias de contar que intervêm na vida, construindo rituais, prometendo expressão, abrindo o significar a novos modos sociais e validando sistemas de valores apreciativos.

Ou seja, há um cruzamento e uma contiguidade entre as imagens-estilode-vida e sua efetiva disseminação na vida cotidiana. Assim é que o consumidor midiático médio da série é também, virtualmente, seu protagonista: "todos cremos que somos protagonistas porque somos espectadores" (RINCÓN, 2006, p. 58). Por esta via, assume-se que uma imagem, no sentido mais amplo, é uma construção cultural habitável, mais do que uma materialidade em si. A amplitude destas 
relações, como apregoa o antropólogo Everardo Rocha, pode ser vislumbrada com a investigação das "relações sociais, éthos, valores, ideologia e estrutura desta sociedade [industrial] que, forçosamente [esbarra] nas indicações precisas daquilo que ela reproduz de nós e do que produz para nós" (ROCHA, 1995, p. 45). Edgar Morin considera que "não é possível [dissociar a imagem] da presença do mundo no mundo, da presença do homem no mundo" (MORIN, 1997, p. 42). Esta questão relevante coaduna com a ideia de construção de uma cidadania amparada pelas relações geradas a partir da comunicação, defendida por Rose de Melo Rocha:

uma cidadania visual, de acordo com esta acepção, implica em considerar que toda imagem conta mil histórias e, por suposto, toda história pode e remete a imagens, sejam elas endógenas, sejam elas exteriorizadas, transformadas em representação, sejam elas visibilizadas (para obterem legitimidade), sejam elas invisibilizadas (para permanecerem no limbo dos estigmas e dos estereótipos) (ROCHA, 2009, p. 277).

Os vínculos que se estabelecem entre homens e imagens reverberam, efetivamente, em universos partilhados de sentido e, obviamente, em dinâmicas de inclusão e exclusão. É o caso, por exemplo, da cultura da celebridade, que transforma o entretenimento em objetivo de vida (RINCÓN, 2006, p. 57), sendo, nestes termos, um projeto hegemônico coletivamente partilhado e, inclusive, apropriado em direções disruptivas. Conforme explica o pesquisador Samuel Matheus "a confluência de imaginários que permeiam a sociedade configura um imaginal público" (2013, p. 47). É neste processo que as imagens não mais exibem sua constituição elementar, mas passam a carregar projeções dos componentes do grupo ou da sociedade por onde circularam. Entende-se que "partilhar um imaginário é também trocar percepções, é distribuir a mesma coleção de representações visuais do mundo, é construir um caminho comum em que nos vemos a nós mesmos e aos outros" (MATHEUS, 2013, p. 33).

Sob o prisma da comunicação, os imaginários que envolvem uma imagem são tão importantes quanto o estudo da imagem em si, remetendo a contextos que a viabilizaram e a valores e disputas de poder que fazem, historicamente, 
variar seus significados, suas formas expressivas, seus traços distintivos e sua relevância. Assim, o processo de mediação que as envolve,

corresponde à percepção de que não temos o conhecimento direto dessa realidade - nosso relacionamento com o "real" é sempre intermediado por um "estar na realidade" em modo situacionado, por um ponto de vista - que é social, cultural, psicológico. O ser humano vê o mundo pelas lentes de sua inserção histórico-cultural, por seu "momento" (BRAGA, 2012, p. 32).

Deste modo, a relação imagens-imaginários é plástica e mutável, mas também orgânica e contínua:

No imaginal público, as representações não são apenas conteúdos trocados entre dois atores (individuais ou coletivos); o imaginal consiste em imaginários publicamente construídos, um coletivo incessante, sempre em estruturação e construção. Assim, um imaginário não é tanto um conjunto fixo e inerte de representações figuracionais de conceitos, mas sobretudo algo que está sempre se fazendo e mudando (MATHEUS, 2013, p. 45).

E "esse mesmo movimento que valoriza a imagem impele-a, ao mesmo tempo, para o exterior, e tende a dar-Ihe corpo, relevo, autonomia. Trata-se aqui de um processo humano fundamental, o da projeção ou da alienação" (MORIN, 1997, p. 43). Entende-se, pois, que "o imaginal designa, no fundo, a variedade dinâmica do imaginário" (MATHEUS, 2013, p. 48). A proposta de uma imagética do consumo (ROCHA, 2006) busca incluir as movimentações, filias e entrechoques advindos da produção e recepção de imagens que, muito fortemente, participam de projetos de visibilidade articulados a dinâmicas inconscientes. Ou, como argumentaria Prokop (1986), existe nos produtos massivos (audiovisuais) uma organização psíquica do conhecimento e da fantasia. E é neste aspecto que o autor caracteriza a fantasia regressiva - repetitiva e esquemática - à esfera da indústria cultural, à televisão muito fortemente.

Ciro Marcondes Filho, na edição brasileira da introdução à obra de Prokop (1986), nota que, para o autor, "os meios de comunicação para as massas não 
difundem ideologias no sentido de 'imagens de mundo', mas representam, por meio de sua significação, valores afetivos sociais, que se encontram na sociedade de forma 'modal'"' (1986, p. 21). Podemos complementar: as audiovisualidades seriadas, em sua gênese norte-americana sessentista, acionam mecanismos modais, mas também mobilizam afetos que podem resultar não apenas em "formas estandardizadas de experiência" (MARCONDES, 1986, p. 20).

\section{Consumo imagético e modalização imaginária: uma mágica afetual sessentista}

O manifesto, o implícito, o constituinte e a experiência. A construção a partir do que é uma imagem e do que ela carrega de projeções imaginárias, que contextos e simbolismos sociais marcam sobremaneira seu percurso para que ela possa fazer sentido, ser compreendida e vivenciada. Fazer sentido seria o destino fim de toda imagem, para existir em sua potencialidade e em seu devir desejante. O poder, logo, residiria na ideia de uma imagem representar algo que faça sentido ou que seja dotada de potencialidade de afecção. É possível sugerir que representações são construções projetivas de um grupo ou de uma sociedade sobre imagens que ocupam o lugar de outras explicações e que usam elementos simbólicos - ou signos - existentes nos contextos que as possibilitam existir.

As premissas de que "o nosso mundo rapidamente se tornou um mundo onde habitam imaginários; o imaginário sendo outra forma de interpretar a realidade e produzir significados" (MATHEUS, 2013, p. 33) e de que "a cultura dentro desta produção simbólica é de uma sociedade inventada por outra" (ROCHA, 1995, p. 45) ressaltam o caráter projetivo de sentidos circunscritos a uma imagem. Se, por projeção, sugere-se a existência de um ponto de chegada e o encontro do desejo com sua satisfação, o acesso para a compreensão desta dinâmica pode ser encontrado na teoria psicanalítica, na perspectiva de Dieter Prokop: 
subdesenvolvimento ou de sua força explosiva. Continuamente obrigadas a se manterem enigmáticas sob a pressão do princípio de realidade - pois uma formulação verbal aberta aos desejos seria destrutiva tanto psíquica como socialmente e provocaria a defesa -, estruturas sociais e individuais diferenciadas de interação e de tempo sobrepõem-se na estrutura dos produtos da cultura de massa (PROKOP, 1986, p. 122).

Estes fenômenos são assim abordados por Douglas Kellner:

Para começar, a cultura da mídia põe à disposição imagens e figuras com as quais seu público possa identificar-se, imitando-as. Portanto, ela exerce importantes efeitos socializantes e culturais por meio de seus modelos de papéis, sexo e por meio das várias "posições de sujeito" que valorizam certas formas de comportamento e modo de ser enquanto desvalorizam e denigrem outros tipos (KELLNER, 2001, p. 307).

Entretanto, o próprio Kellner aponta para a necessária leitura social e ideológica das imagens e representações veiculadas pela mídia,

porque as representações dos textos da cultura popular constituem a imagem política por meio da qual os indivíduos veem o mundo e interpretam os processos, os eventos e as personalidades políticas. A política da representação, portanto, examina as imagens e as figuras ideológicas, assim como os discursos que transcodificam as posições políticas dominantes e concorrentes numa sociedade (KELLNER, 2001, p. 82).

Mesmo se levarmos em conta a direção de sentido pretendida, sabemos que está implicada em uma gama de recepção ampla, com diferentes hábitos, expressões de religiosidade, práticas de entretenimento, modos de pertencimento, de constituição dos jogos e regras para a aprovação inter-relacional, de referencialização, entre outros:

A cultura, em seu sentido mais amplo, é uma forma de atividade que implica alto grau de participação, na qual as pessoas criam sociedades e identidades. A cultura modela os indivíduos, evidenciando e cultivando suas potencialidades e capacidades de fala, ação e criatividade [...] [porque] as pessoas passam um tempo enorme ouvindo rádio, assistindo à televisão, frequentando cinemas, convivendo com música, fazendo compras, lendo 
revistas e jornais, participando dessas e de outras formas de cultura veiculada pelos meios de comunicação. Portanto, trata-se de uma cultura que passou a dominar a vida cotidiana (KELLNER, 2001, p. 11).

Ou seja, fazer sentido envolve um plano de conformidade - fazer parte de um grupo e do processo de aceitar os códigos que constituem seus integrantes. Mas, como bem o provam os esforços sedutores e sofisticados das indústrias do entretenimento, envolve um plano irremediável de negociação, amplificado justamente pela situação massiva, cada vez mais difusa e diversa, que passa a caracterizar as audiências comunicacionais em contextos domésticos. O uniforme, pois, negocia com o diverso e a ambivalência - seja ela narrativa, presente na caracterização dos personagens ou na articulação real/ficcional -, prestando-se ao equacionamento, mas não à determinação, de propostas ou convites de adesão público/série.

Neste sentido, não é possível esquecer que, por trás e através da ideologia, há a perspectiva do poder relacionado à transmissão das referências, a serviço de quem produz a mídia. Na ótica de Roger Silverstone, quando se dedica a analisar a construção e a experiência através do midiático, parte-se da inserção destas manifestações e produções culturais na vida cotidiana, em algumas de suas várias possibilidades. Por sua vez, o foco origina-se nas lentes subjetivas e/ou individuais - baseadas em sua constituição, experiências social e pessoal -, com as quais se relacionam, compreendem, participam e produzem sentidos. Isto se aplica, inclusive, para os textos midiáticos que Ihes tocam, e que, em outro extremo, possuem dimensões e implicações mercadológicas, políticas ou econômicas.

A partir da década de 1960, "consolida-se uma cultura do consumo que é intrinsicamente articulada à midiatização do real. Isto significa falar da aproximação irreversível entre consumo e a cena cultural tecida pelo universo da comunicação massiva" (ROCHA, 2012, p. 24), cuja essência e estruturas subjetivas já se encontravam preconizadas e atuantes algumas décadas antes, por exemplo, no cinema, em revistas, em jornais e no rádio. A função do consumo imagético projetivo compõe o DNA do "campo mais amplo da produção e da recepção midiáticas" (Ibid., p. 24) - no caso, então, através do rádio e do cinema. Este é 
o cenário em que "a centralidade das imagens visuais e das imagens imaginadas [permite] pensar o consumo, suas práticas e dinâmicas" (ROCHA, 2012, p. 22), retrato de um tempo-histórico e de um tempo-comportamento que captou uma "nova sociedade [que] apresentou um 'estilo de vida', uma determinada 'visão de mundo' que reordenou a experiência existencial do ser humano" (ROCHA, 1995, p. 106), inclusive e especialmente o consumo das próprias imagens e referências, concretas e aspiracionais, conscientes ou projetadas.

A visibilidade relacional que o consumo - como narrativa do capital e como processo sociocultural amplo - apresenta como valor reside na "relação entre a potencialidade da sedução das imagens com a apresentação de imagens relacionadas a estilo de vida" (ROCHA, 2012, p. 28). Reitera-se em séries como $A$ feiticeira a promessa de progresso e dignidade civil, outro fundamento da sociedade norte-americana. Mas não se trata de progredir de qualquer forma, ainda que

tal postura [dê] às pessoas forças para se vestirem e se comportarem como quiserem, para serem o que quiserem, ao mesmo tempo [...] as escraviza à necessidade de criar uma imagem, de ter pose, de construir a própria identidade por intermédio do estilo, obrigando-as a se preocupar com o modelo de vestir-se, com a aparência, com a reação alheia à sua imagem (KELLNER, 2001, p. 365).

\section{Estilos de vida, estilização comportamental}

A milionária norte-americana Amy Vanderbilt (1908-1974) pode ser considerada uma precursora de estratégias hoje adotadas pela família Kardashian, que em sua famosa série-reality Keeping up with the Kardashians serializa o próprio cotidiano, espetaculariza seu dia a dia e o oferta ao consumo midiático 4 . Vanderbilt trabalhou em programas de rádio e TV e escreveu sobre comportamento e etiqueta social. Em O livro de etiqueta de Amy Vanderbilt (1962), postula que o termo etiqueta "expressa muito mais do que 'maneiras' [...] porque todos nós devemos aprender as regras da vida em comunidade, qualquer que seja a sociedade 
em que nos encontremos" (VANDERBILT, 1962: XIX-XX). Sublinhava, assim, a existência de um modo de viver, ou melhor, de um estilo de vida que é inclusivo e valorativo. Para aplicar sua orientação de disseminação destas regras, tal estilo de vida deveria ser exibido como referência. A força da forma-mensagem residia, dentre outros aspectos, na amplificação e glamourização do espelhamento projetivo propiciado pela comunicação massiva. Assim, uma personagem excepcional, ícone de distinção, gentilmente se oferecia para educar as multidões. Mocinhas e rapazes, vida pública e privada, mundo doméstico e do mundo do trabalho, nada escapava ao escrutínio da refinada e conservadora Amy. Do alto de sua distinção de classe ela se dirigia aos mortais - ou os neoplebeus da sociedade burguesa - e Ihes lançava uma perspectiva imagético-imaginária de inclusão, prescritiva, disciplinar e sedutora... Afinal, mesmo aos fracassados e perdedores não seria negado o direito a dominar as boas regras de vida em comunidade.

Tem-se a estilização de um modo de viver, individual e amparado em grupos de inserção e em grupos de identificação, com características idealizadas e modelares, composto por exteriorizações deste estar e ser na sociedade à qual se pertence, ou à qual se deveria pertencer. Trata-se de um fenômeno amplo, de produção de sentidos na ordem da constituição identitária, fundamentada no modo de viver associado à posse, que oferece valor simbólico e valorativo ao indivíduo e ao seu grupo social. Como consequência, é possível discutir o modo como se estabelece a construção de representações que traduzem a ideia de estilo de vida e os processos de reprodução e de transmissão de imagens modelares.

Estas representações materiais e audiovisuais tornaram-se sinalizadoras de um modo de viver triunfante, no qual consumir vai além do ato de comprar e usufruir de uma mercadoria. Trata-se, reconhecidamente, de um instrumento de diferenciação, de classificação e de distinção:

A alteração no padrão do comportamento das pessoas imposta pela preeminência das máquinas, das engenharias de fluxos e do compasso acelerado do conjunto, como seria inevitável, acaba também provocando uma mudança no quadro de valores da sociedade. Afinal, agora os indivíduos não serão mais avaliados pelas suas qualidades mais pessoais 
ou pelas diferenças que tornam única a sua personalidade. Não há tempo nem espaço para isso. [...] e são tantos e estão todos o tempo todo tão ocupados, que a forma prática de identificar e conhecer os outros é a mais rápida: pela maneira como se vestem, pelos objetos simbólicos que exibem, pelo modo e pelo tom com que falam, pelo jeito de se comportar (SEVCENKO, 2001, p. 63-64).

Parte significativa da produção cultural e midiática no século XX foi produzida pelos Estados Unidos e ultrapassou suas fronteiras, mundializando-se. Televisão, cinema, rádio, revistas e jornais expuseram a imagem idealizada perseguida pelo país: nação progressista, igualitária, democrática e forte. Tratar-se-ia de uma sociedade pretensamente composta por uma maioria de cidadãos sadios, educados, limpos e éticos, que se organizavam em núcleos familiares e sociais, e que serviriam de modelo para seu próprio povo como para tantos outros que assistiam a filmes ou que acompanhavam a seriados na TV na década de 1960. As formas de comunicação oriundas daquele país apresentavam-se como prova de superioridade em bens, conforto, segurança e em etiqueta e traquejo social, para que não nos esqueçamos da lição de madame Vanderbilt. Mas este pertencimento, na inclusão generosa sugerida, é, na verdade, um poderoso motor distintivo:

[a] comunicação básica, aquela que precede a fala e estabelece as condições de aproximação, é toda ela externa e baseada em símbolos exteriores. Como esses códigos mudam com extrema rapidez, exatamente para evitar que alguém possa imitar ou representar características e posição que não condizem com sua real condição, estamos já no império das modas. As pessoas são aquilo que consomem. [...] em outras palavras, sua visibilidade social e seu poder de sedução são diretamente proporcionais ao seu poder de compra (SEVCENKO, 2001, p. 64). ${ }^{5}$

Esta ambivalência inclusão-diferenciação pauta a lógica de visibilização desta proposta de sociedade, igualitária ma non troppo, isto porque há um modelo narcíseo-individualista subjacente a sua expectativa de triunfo. Estamos em um momento primordial da serialização massiva made in America, que se 
desdobrará, posteriormente, em práticas de consumo midiático segmentadas, com o estabelecimento de vinculações identitárias quentes e táteis, extremamente personalistas e personalizadas. Nesta etapa original, a comunicação audiovisual firma-se como forma privilegiada de expor os traços deste nacional-mundialismo do espetáculo, das frivolidades, mas também da retidão e da superação, embalados pela

cultura de consumo [que] usa imagens, signos e bens simbólicos evocativos de sonhos, desejos e fantasias que sugerem autenticidade romântica e realização emocional em dar prazer a si mesmo, de maneira narcísica, e não aos outros (FEATHERSTONE, 1995, p. 48).

A midiatização das relações e imagens de progresso, pujança e bem-viver alcançou muitas outras sociedades e culturas, mantendo presente um processo de "produção de preferências distintivas por estilos de vida e bens de consumo" (FEATHERSTONE, 1995, p. 124). A construção de um conceito de "estilo de vida" ao longo do século XX movimentou-se entre imagens que descreviam um modo de estar na sociedade e o caráter projetivo do indivíduo para o grupo, do grupo para a nação e da nação para o mundo. O estilo de vida passou a simbolizar uma forma de viver e de traduzir valores que mantém íntima relação com o consumo ${ }^{6}$.

Featherstone se utiliza do conceito de estilo de vida para ponderar acerca da relação subjetiva que indivíduos e grupos sociais utilizam para com suas expressões e subjetividades:

\footnotetext{
A expressão "estilo de vida" está atualmente em moda. Embora tenha um significado sociológico mais restrito, designando o estilo de vida distintivo de grupos de status específicos [...], no âmbito da cultura de consumo contemporânea ela conota individualidade, autoexpressão e uma consciência de si estilizada. O corpo, as roupas, o discurso, os entretenimentos de lazer, as preferências de comida e bebida, a casa, o carro, a opção de férias etc., de uma pessoa são vistos como indicadores da individualidade do gosto e o senso de estilo do proprietário/consumidor (FEATHERSTONE, 1995, p. 119).
} 


\section{Uma cozinha, uma televisão e uma sala de estar: o mundo ideal do comum-excepcional}

O poder de um chefe de família indo para o trabalho garantir a subsistência de seu lar. O poder da mulher, esposa e mãe, com a capacidade de organizar e de manter sua casa e seu núcleo familiar em perfeita ordem, contando para tal tarefa com inúmeros produtos e aparelhos eletrodomésticos. As famílias unidas, os amigos do bairro, o sonho conquistado da faculdade, a hipoteca que possibilitaria acesso à casa própria, os filhos, eventualmente uma profissão glamourosa. Imagens contundentes de um estilo de vida, presentes na vida cotidiana, nas ruas e nos veículos de comunicação. Estereótipos que estabeleciam padrões de comportamento e de desejabilidade.

Em cada sala onde ocupava um local de prestígio - quase totêmico - , a TV se incumbiu de caracterizar e amplificar o escopo das representações de um estilo de vida promissor e de um cidadão consumidor-espectador, levando para dentro dos lares a projeção do que seria esta trajetória modelar e a correlata temporalização que demarcaria idealmente sua realização.

As imagens do american way of life, no qual a serialização torna-se, de fato, um estilo e uma etiqueta, puderam ser fortemente visualizadas em produtos midiáticos da primeira metade da década de 1960 . Seriado norteamericano consagrado, a segunda atração mais vista no país em seu ano de estreia, A Feiticeira, veiculado nos Estados Unidos entre os anos de 1964 a 1972, apresenta uma modelar dona de casa, Samantha (interpretada pela atriz Elizabeth Montgomery), que aparentemente possui tudo o que deseja: um marido apaixonado e dedicado, uma família de origem, uma casa no subúrbio nova-iorquino, itens de consumo de última moda, elegância, beleza e (depois) filhos.

Ela poderia, de fato, não apenas desejar, ela poderia realizar tudo, pois é uma feiticeira, fato que revela a seu mortal marido durante a lua de mel. Sob a interdição conjugal e padecendo de certa culpa introjetada, Sam se recusa a usar seus poderes para conseguir algo a mais do que sua invejada vida já contempla, apregoando que a vida normal é mais importante e real, algo que soava bem 
a tantas mulheres - não só daquele país -, acomodadas ou impossibilitadas de viverem de tal maneira, ou ainda, referendando o que outras já experimentavam.

Samantha relaciona-se de modo muito casual com as comodidades da vida moderna. Ela se mostra mais centrada, sem deslumbramentos. Era a vida prometida a quem labuta e faz sua parte como filho de Deus e como parte de uma nação promissora e vencedora. Logo, a visibilidade de sua vida exalta o modelo de casa, casamento, família e atitudes esperadas por uma dona de casa norte-americana, bem ajustada à vida moderna e feliz. Ela mora num subúrbio em casa confortável, que para pessoas de outros países até poderia sugerir riqueza - todavia, é apenas uma boa casa de classe média suburbana para aquela sociedade. O compreensível espaço mais moderno desta casa é a cozinha, onde invejáveis equipamentos e eletrodomésticos dão conta de justificar a exemplaridade da tecnologia e da praticidade. Note-se que Samantha prefere usar seu tempo e esforço para cozinhar, enquanto poderia fazer surgir o melhor jantar num passe de mágica.

Os eletrodomésticos remetem a este universo mágico realizado. Como na própria estrutura narrativa dos seriados, há uma promessa de paz e triunfo que era, ao mesmo tempo, uma convocação peremptória à organização do próprio tempo - e, obviamente, da própria sexualidade. Planificam-se nos rituais cotidianos: o café da manhã com o marido (indo para o trabalho) e as crianças (paulatinamente indo à escola), os jantares para os chefes do pai da família ou com a família da esposa (em A Feiticeira esta é a ênfase), as visitas da vizinha durante o dia, e, claro, a televisão, que traz o surpreendente mundo para dentro de casa.

Os demais personagens estabelecem o contraponto com o que advinha das imagens de vida idealizada e de consumo. James, o marido dedicado (o ator Dick York na primeira temporada da série), é um publicitário trapalhão no auge desta atividade no mundo. Endora (a atriz Agnes Moorehead), mãe de Samantha e igualmente feiticeira, ${ }^{7}$ valoriza a obtenção do que se quer através da magia.

7 N. do A.: uma das brincadeiras promovidas nos episódios é Endora ser chamada de bruxa, enquanto encarnação de uma sogra com problemas de relacionamento com o genro. Trata-se de outra evocação do imaginário social. 
Seu pai, Maurice, um mago, encarna o aristocrata, a elegância e o gosto pelos prazeres da vida. Agnes, sua vizinha, é uma loser e não obtém sucesso em suas empreitadas porque mantém a premissa da ostensiva comparação e preocupação com os outros - infringindo uma regra de ouro da sociedade norte-americana, o direito à privacidade.

Deste modo, percebe-se que há uma crítica implícita à possível facilidade da personagem em adotar formas mais fáceis para gerir seus problemas cotidianos. Embora, por vezes, tenha que usá-la para questões específicas, é na magia que residem seus maiores problemas. A vida real e possível prevalece como valor. Samantha aceita os limites - e os esquece, sempre pelo bem de sua família, nunca em benefício próprio - e não os questiona -, pois fazem parte da vida perfeita que quer levar. Seu estilo de vida é uma postura moral.

Enquanto produtos midiáticos, os seriados televisivos são filhos de seu tempo. Este processo ambivalente tornou-se mais interessante à medida que o que não era modelar - ao estar presente na série - contribuía para maior verossimilhança, colaborando tanto para a delação dos conflitos como para o reforço do estilo de vida apresentado como modelo. Nestas ambivalências estilizadas entre cotidiano/espetáculo, machismo/feminismo, casa/trabalho Samantha é a operadora mágica, ela mesma contendo o imaginário da garota boa-má, a dona de casa bela, casada e convencional, e a mulher independente, solteira e sedutora (materializada por sua prima, Serena).

Elizabeth Montgomery faleceu aos 62 anos, de um câncer fulminante. Em uma de suas biografias declara ter passado a vida tentando ser feliz. Conta-se que nos sets de A feiticeira despertou a paixão, não correspondida, de York, intérprete de seu marido James Stephens nas primeiras temporadas da série. Dizia-se, em tom de especulação irônica, que não por acaso se selecionou Dick Sargent, assumidamente gay, para protagonizar o segundo James. William Asher, um dos maridos de Montgomery e produtor de inúmeros episódios da série, não Ihe era fiel. Ela, igualmente, terminou o abandonando para viver com um dos roteiristas de $A$ Feiticeira. Até estabelecer uma parceria 
conjugal longeva, Montgomery enfrentou percalços muito diversos da vida da personagem modelar que a conduziu ao imaginário de muitas gerações. Seu primeiro cônjuge, o aspirante a produtor Frederick Gallatin Cammann, por sua vez, queria que Elizabeth abandonasse a carreira e se tornasse uma dona de casa e mãe. Ela recusou. Ele a abandonou. Na vida real, a sucessão de episódios nem sempre conduzia a finais felizes. Mesmo no mundo encantado do estrelato televisivo.

\section{Referências}

BRAGA, J. L. Circuitos versus campos sociais. In: JACKS, N.; JANOTTI JUNIOR, J.; MATTOS, M. A. (Org.). Mediação \& midiatização. Salvador: Edufba; Brasília, DF: Compós, 2012. p. 31-52.

CUNHA, P. R. F. American way of life: representação e consumo de um estilo de vida modelar no cinema norte-americano dos anos 1950. Tese (Doutorado em Comunicação e Práticas do Consumo) - Escola Superior de Propaganda e Marketing, São Paulo, 2015.

DEBORD, G. A sociedade do espetáculo. Rio de Janeiro: Contraponto, 1997.

FEATHERSTONE, M. Cultura de consumo e pós-modernismo. 1. ed. São Paulo: Studio Nobel, 1995.

JAMESON, F. Pós-modernismo: a lógica cultural do capitalismo tardio. São Paulo: Ática, 1996.

KELLNER, D. A cultura da mídia: estudos culturais - identidade e política entre o moderno e o pós-moderno. Bauru: Edusc, 2001. 
MATEUS, S. O imaginal público: prolegómenos a uma abordagem comunicacional do imaginário. Comunicação, mídia e consumo, São Paulo, ano 10, v. 10, n. 29, p. 31-50, set./dez., 2013.

MORIN, E. O cinema ou o homem imaginário: ensaio de antropologia. 1. ed. Lisboa: Relógio D’Água, 1997.

- Cultura de massas no século XX: necrose. 3. ed. Rio de Janeiro: Forense Universitária, 1999.

PROKOP, D. Sociologia. 1. ed. São Paulo: Editora Ática, 1986.

RINCÓN, O. Narrativas mediáticas: o cómo se cuenta la sociedad del entretenimiento. Barcelona: Gedisa, 2006.

ROCHA, E. P. G. A sociedade do sonho: comunicação, cultura e consumo. 4. ed. Rio de Janeiro: Mauad, 1995.

ROCHA, R. M. É a partir de imagens que falamos de consumo: reflexões sobre fluxos visuais e comunicação midiática. In: BACCEGA, M. A.; CASTRO, G. G. S. (Org.). Comunicação e consumo nas culturas locais e global. São Paulo: ESPM, 2009. p. 268-293.

A pureza impossível: consumindo imagens, imaginando o consumo. In: ROCHA, R. M. ; CASAQUI, V. (Org.). Estéticas midiáticas e narrativas do consumo. 1. ed. Porto Alegre: Editora Sulina, 2012. p. 21-48.

SEVCENKO, N. A corrida para o século XXI: no loop da montanha-russa. 1. ed. São Paulo: Companhia das Letras, 2001. 
SILVERSTONE, R. Por que estudar a mídia? 1. ed. São Paulo: Loyola, 2005.

VANDERBILT, A. O livro de etiqueta. São Paulo: Record, 1962.

submetido em: 27 jul. 2017 | aprovado em: 30 ago. 2017 